\title{
The Impact of ERP System on the Customer Performance: A Case Study in the Institution of Higher Education in Kingdom of Saudi Arabia
}

\author{
Hussain Ahmad Awad \\ MIS Department, Faculty of Business - Khulais, University of Jeddah, Jeddah, KSA
}

Email address:

Almalky24@yahoo.com

\section{To cite this article:}

Hussain Ahmad Awad. The Impact of ERP System on the Customer Performance: A Case Study in the Institution of Higher Education in Kingdom of Saudi Arabia. International Journal of Economics, Finance and Management Sciences. Vol. 4, No. 3, 2016 , pp. 138-142. doi: $10.11648 /$ j.ijefm. 20160403.16

Received: March 6, 2016; Accepted: March 21, 2016; Published: May 11, 2016

\begin{abstract}
ERP system has become one of the most primary pillars that organizations depend on to guarantee a great success in the markets. The significance of ERP has been proved through its obvious privileges by various studies in this field. The former successful history of these systems depends on the value added on organizations performance; therefore, its influence on organizations has been considered among the hottest topic till qualitative and quantitative measures have come into application in order to determine the success or failure of enterprise system. Having an overview on the previous studies of ERP system evaluation, one will find that the impact of this system on external consumer has been excluded in spite of being a fundamental part of organization's environment. The researcher aims at investigating the effect of ERP systems used at universities on the students' academic performance through which a field study will be held 'in three universities with an updated ERP system.
\end{abstract}

Keywords: ERP System in the Institution of Higher Education, System Internal Customer, System External Customer Performance

\section{Introduction}

There are a lot of badly needed requirements for any ongoing successful work environment to demonstrate its presence in the markets. Such example is the aggressive cost control initiatives need to analyze cost/revenues on a product or customer basis, flexibility to respond to changing business requirements, more informed management decision-making, and changes in ways of doing business.

It seems problematic for an individual system to provide all necessary requirements. From this perspective, enterprise systems have emerged and provided an ERP system by which all organization's operations are integrated in one enterprisewide solution. Holland defined Enterprise Resource Planning as "system is a multi-module transaction-based application that helps organizations to manage the vital parts of the business". [7]

ERP system is classified among wide-systems that cover all required operations of an organization from its raw material to the distribution that is performed through an enterprise management information system. Due to the tremendous services and continuous success of these systems on business enterprise, it has come to attention for all public organizations to employ these systems so as to manage and benefit from their privileges. This, in turn, has been widely expanded to all private and public organizations which provide profitable or unprofitable services based on an ERP system.

Previous studies have mentioned a greater success for ERP system in many sectors in spite of its exorbitant cost which might exceed 20 million dollar. [1] These successes have been proved by carrying out a number of researches about the impact of these systems on the performance of an organization. For instance, $[3,4,5]$ depend on the following criteria: Functionality, cost, service delivery, reliability, usability, implement-ability, risk, maintainability, contribution to business strategy, and efficiency.

The shortcomings of these criteria lie behind their fully 
concentrating on the impact of these systems on the organization's operations ignoring their tangible impact on consumers. In this connection, it should be mentioned that consumer's opinions are considered as one of the most significant criteria to the success of these systems. Moreover, enterprise systems are differed from others by having two types of consumers: The internal user is the organization's employee who deals with almost all kinds of systems inside the organization. The other is the external user who is categorized as the final input of supply chain will also receive the products and services of the organization and named as a traditional consumer. [11]

In addition, various studies such as [3, 4, 18] have indicated the impact of ERP system on the internal user being a basic part of the organization's operation. The researcher seeks to address the impact of successful ERP systems on the external user so as to explain whether they are indeed successful from the customer's point of view as it is already in the enterprise's operations.

\section{Research Methodology}

This current study depends on a questionnaire that will be distributed on 300 students from three Saudi universities as a sample of unprofitable public organizations. These universities are as follow: Umm Al-Qura University, King Abdulaziz University, and Jeddah University. The reason that lies behind the selection of these three universities in particular, despite of having 28 universities in the kingdom, was the updated copy of ERP system around two years ago through which current students have experienced the two system's copies. The researcher has determined eight dimensions to elucidate if the updated ERP system has actually influenced the students performance. These dimensions have been collected from evaluation models of students' performance in the following three universities: University of South Carolina Upstate, University Avenue West Waterloo, and the Collage of Davidson \& Davie Counties. [20, 21, 22] It is worth mentioning that the researcher has selected the students of Management Information System Department as a sample of the study for various tangible and significant results such as the direct contact of the researcher with the students, their knowledge of the system terminology, and the availability of their results before and after the updating of the system. Also, the students of the third and fourth year have been purposefully chosen due to their experience with the two system's copies.

\section{ERP System in the Institutions of Higher Education in the Kingdom of Saudi Arabia}

ERP systems have been used by both organizations that provide services as well as by those organizations that provide products such as insurance companies, hospitals, banks, Governmental public services, higher education institutions .....etc. The universities have replaced their traditional administrative systems with ERP systems in order to encompass its entire administrative and academic works. This will result in the improvement of its provided services through efficiency improvement and minimize costs. [4] In this conjuncture, most universities have exploited ERP systems to save time and money which has been reflected on their internal and external investment returns. These investments face numerous administrative and technological challenges, and even stakeholder expectations in the universities. Some more challenges refer to the unstable complexity, ramification, and variations of university processes.

Saudi universities have set out the application of ERP systems in an effort to improve and decrease its electronic services. That is to say, Saudi government has allocated almost 29 billion dollar for 2015 budget to develop and support the academic and administrative universities' works. [13] Major corporations such as Oracle and SAP that provide ERP systems have shared the building of this system in Saudi universities. Some universities are still working on the former copy in their systems while others such as those selected in the study have updated their ERP system in 2014. Accordingly, it can be concluded that Saudi universities have reached a high level of dealing with ERP systems. In other words, it could be relied on their performance evaluation and generalize the results on the population of the study as return on investment has emerged on actual performance. Many previous studies have talked about universities' evaluation of ERP systems from the point if users evaluation as in $[14,8]$ while Other studies have concentrated on critical success factors (CSF) [16, 18]. Some universities have declared through their websites how successful their systems are by increasing the efficiency of its operations and achieving the desired objectives. [9, 10, 17]

\section{ERP Systems' Users}

One of the reasons that lies behind the emergence of ERP system and its increasing in the number of organizations which use the system was Y2K. Accordingly, ERP system has become an attractive topic to investigate and to find the factors affecting its success. There were many previous studies that have evaluated the impact of ERP system on organizations and economy, yet few of them have done the same on system's users informed that they are more capable to assess its success. The most important factor in the changing or updating of any system refers to the users' demands; neglecting this matter might result in the obvious system's failure as being described in the previous studies [3, $6,15]$. The improvement of operations' efficiency is what organizations keep in its priorities not the increasing of user's creativity and productivity. In this regard, organizations should give attention to the significance of system users because they are among the three primary factors of organization's success; these factors are methodology, tools, and users. [5] 
There are three main parts who deal with an ERP system: the first type is the consumer who purchases the system and be represented by the Governing Council or the organization's owner as the government in the case of governmental organizations. This type satisfaction could be achieved by measuring its impact on the organization's performance, long-term goals, system's cost, and return on investment. The second type is the organization's employee who deals with the entire system inside the organization boundaries. Its satisfaction depends on various variables such as what the system may provide to increase its adaptability, knowledge, and job satisfaction. The third type is the external system user which is usually expressed by the mediator, the supplier, ultimate consumer, or the recipient of the services provided by the organization. [19]

According to the previous mentioned studies, it can be concluded that they have focused on the first two types and the impact of an ERP system on them while the third type has not received any attention that expresses the impact of ERP system on the external user particularly in the public organizations. External user plays an influential role on public organizations that provide ERP services such as the universities because he receives the services very frequently through the system. For instance, these systems provide the student with academic services like managing personal and academic student record, registration operations, viewing reports with tables and marks, following up students' progress, contacting with students and teachers via SMS or Email, providing electronic library services, students accommodation, financial transactions, academic advising.....etc. In this case, the student is considered the ultimate consumer of the university academic services; therefore, his opinion about the system should be taken seriously to measure the impact of these updated systems on his academic performance. The message, goal, and vision of any university shall meet to raise the student's academic level through the designed investments of the university projects. The question to be posed here: Do the funds invested in building or updating ERP systems contribute in improving the student performance or even affect it?

\section{The Impact of ERP Systems Used at the Universities on the Student's Performance}

The consumer's satisfaction on the provided services is basically connected with its value of quality and cost. [19] Accordingly, students do care about the academic services provided by the university not the system itself which is used as a supported tool. This does not stand in contract with the significance of ERP system nor being a helpful tool in the student's educational life. But do these systems affect the student performance in line with the invested huge amount of funds? Do students need all these additional and complex services to have an academic progress? And are students fully aware of all these services provided by

\section{ERP systems?}

The researcher has briefed ERP systems existing in the sample of the study and subsequently finds they are divided into four sections: the financial system, human resources, logistic system, and e-learning or academic system which students can freely use. The rest of the system services are used by the internal user. Whereas quarter of the system is concerned with the student's record and services. In this conjuncture, there is no evaluation to the impact of this part on the user's performance, and the whole previous studies were purely interested in the evaluation of the system's performance. For example, king Fahd University of Petroleum and Minerals (KFUPM) has made an evaluation to its own ERP system by posing the following general questions: what are the most satisfied services provided by the system to the users? And how could we solve unsatisfied services according to the user's opinion? Up to this time, KFUPM did not publish the evaluation's results. [9] Both king Abdulaziz University (KAU) and University of Jeddah (UJ) have published through their websites that their electronic management, which has been applied in cooperation with SAP Corporation, is a successful investment in the field of information technology to the benefit of students and their knowledge in the kingdom of Saudi Arabia without publishing any reports on the evaluation procedure to the system. [10] To conclude, the researcher seeks to make an evaluation over the students' benefits of available ERP services at his university, and to determine its practical and actual knowledge of the system.

In order to measure the impact of ERP system on the student's performance, specific dimensions should be determined. Previous studies such as [2, 12] have divided student's performance into three basic sections: Cognitive, Affective, and Psychomotor. each of them is divided into various dimensions and indications to be measured. Such as adaptability, response, analysis, and knowledge....etc. each educational institution depend on an evaluation model of student's performance, and choose a number of dimensions by which the performance is measured. For example, University of South Carolina Upstate, University Avenue West Waterloo, and the Collage of Davidson \& Davie Counties have determined a set of dimensions to measure student's performance but the system could not affect all of them. Therefore, the researcher has chosen eight dimensions that may get affected by the system and its tools. These are as follow: ability to learn, communication, dependability\& cooperation, motivation/initiative, problem solving, quality of work, quantity of work, and grades.

The researcher has distributed a questionnaire on 300 students from the department of Management Information System in the three selected university to measure the extent of ERP system impact on the first seven dimensions of student's performance. Moreover, the researcher depends on a summarized report of students' marks in the years 20132014 before the system's updating, and 2015-2016 after the system's updating. 


\section{Results}

- Ability to learn: $73 \%$ of the students indicated that the system did not help them to increase their educational ability and accomplishing their assigned tasks, 17\% have benefited from the system, and $10 \%$ were neutral.

- Communication: $69 \%$ of the students use the contact services on the system to keep in touch with teachers and other students; they also receive the university's announcements and news through this system. $31 \%$ use different personal contact devices and did not rely on the system.

- Dependability\& Cooperation: $100 \%$ of the students agreed that there is no particular tool on the system to facilitate the social work or cooperation among students nor it motivates active learning.

- Motivation/Initiative: $100 \%$ of the students did not find any motivations on the system to help them accomplish their tasks or even find new ideas or methods of work.

- Problem Solving: 92\% of the students' answers agreed that the system did not facilitate analyzing problems, evaluating alternatives, or even selecting the best solutions. $8 \%$ were neutral.

- Quality of Work: $97 \%$ of the students have not affected by the system on their educational output. 3\% were neutral.

- Quantity of Work: 100\% of the students agreed the system did not affect the outputs of their assigned home works and tasks.

- Grades: according to the reports of students' marks in the department of Management Information System in the three selected universities, their marks in 2014 were as follow: $15 \%$ excellent, $21 \%$ very good, $36 \%$ good, $24 \%$ fair, and 4\% fail. In 2016 which is after the ERP system's updating $12 \%$ excellent, $21 \%$ very good, $35 \%$ good, $26 \%$ fair, and $6 \%$ fail.

- According to the students' answers on the open questions, $70 \%$ of the students use the system to view the course schedule, transcripts, and the period or date of registration. $30 \%$ use the rest of system's services.

The researcher finds out the median for each question in the sample of the study to make sure that all results are symmetric. By using SPSS, the researcher conducts a Non Parametric Chi-Square test through finding P-value. By doing so, the researcher will make sure that the existing mean result is taking into consideration or to delete the question assigned to the dimension. Finally, P-value results have shown between 0.017 and 0.031 which are less than 0.05 . that is to say, all mean's values are statistically considered.

The whole questionnaires were distributed on specialists in the management information system, which in turn emphasize their clear understanding of the ERP system's terminology.

To conclude, the previous results indicated that the students have not been affected by the system on their academic performance in regard to the first seven dimensions. Also, the students' marks repots have not improved before and after the updating of the system. The lack of improvement is not attributed to the system itself, it rather means that the students have not affected academically by the system.

Moreover, the previous results show that ERP system did not support the students' academic performance for two main reasons: either because the students do not know how to function the system or this technology overpasses the students' needs. All the systems in the three selected universities are successful from the enterprise's operations, but unfortunately did not affect the academic performance of students. Therefore, these universities must employ mechanisms to activate these systems and benefited from them in the academic sides, in addition to study the reasons lie behind its lack impact on the students' performance.

\section{Summary}

In this current study, the researcher has focused on the explanation whether ERP systems at the universities can achieve its goals to improve the students' academic performance in their period of study. The following eight dimensions have been selected to measure the impact of these systems on students' performance: ability to learn, communication, dependability\& cooperation, motivation/initiative, problem solving, quality of work, quantity of work, and grades. The results are summarized that these systems play a significant role in the enterprise operations but a weak role in the academic aspects. If we compare the invested money of these systems in the universities' budgets, we will find that these systems should have a greater impact on core business, which is the academic performance. Therefore, the researcher recommends reducing spending on enterprise systems and heading to other options or even searching for new methods to increase its impact on students' academic performance.

\section{References}

[1] Ahed A, Louis S. (2010) Enterprise Resource Planning (ERP) System in Higher Education: A literature Review and Implications. International Journal of Human and Social Sciences Vol. 5, No.6 2010.

[2] Alan R. (2004) An empirical study of the effect of information technology expenditures on student achievement. Information Sciences and Technology, Pennsylvania State University, available at: http://www.informationr.net/ir/94/paper185.html (accessed on May 2015).

[3] BEJJAR M, BOUJELBENE Y. (2013) THE IMPACT OF ERP SYSTEM ON USER PERFORMANCE. Journal of Theoretical and Applied Information Technology, June 2013. Vol. 52 No.3.

[4] Emin G, Aysegul A, Sena A, \& H. Selva S. (2010) An ERP Application In A Non-Profit Organization: Turkish Red Crescent Society. International Journal of Management \& Information Systems - Fourth Quarter 2010 Vol. 14, No. 5. 
[5] Fadi T, Shadi A, Mohammed K \& Excimirey A. (2012) The Effect of ERP Successful Implementation on Employees' Productivity, Service Quality and Innovation: An Empirical Study in Telecommunication Sector in Jordan. Published by Canadian Center of Science and Education, International Journal of Business and Management; Vol. 7, No. 19; 2012.

[6] Fosser E, Leister O, Moe C \& Newman M. (2008) Organisations and vanilla software: What do we know about ERP systems and competitive advantage? Proceedings of ECIS 2008, Galway, Ireland, June 8-11.

[7] Holland, C., Light, B. and Kawalek, P. (1999). Beyond Enterprise Resource Planning Projects: Innovative Strategies for Competitive Advantage. Proceedings of the $7^{\text {th }}$ European Conference on Information Systems, Vol. 1, pp. 288-301.

[8] KAUST, (2015), available at: http://www.kaust.edu.sa/research/management.html (accessed on May 2015).

[9] KFU of P\&M feedback, (2015), available at: http://feedback.kfupm.edu.sa/FS/nsurvey.aspx?surveyid=999e a5482ce42a293bd4243c744f5ce (accessed on May 2015).

[10] King Abdulaziz University, (2015), available at: $\mathrm{http}: / /$ www.kau.edu.sa/content.aspx?site id=0\&lng=AR\&cid= 104133 (accessed on May 2015).

[11] luavai F, Jeff T. (2012) Enterprise systems for management. Second edition, Copyright (C) 2012 Pearson Education, Inc. Publishing as Prentice Hall, pp. 114-119.

[12] McBeath, R. J., Ed. (1992). Instructing and evaluating in higher education: A guidebook for planning learning outcomes. Englewood Cliffs, NJ: Educational Technology Publications.

[13] Ministry of Saudi Arabian Higher education, (2015), available at: http://www.mohe.gov.sa/ar/Pages/Budget.aspx (accessed on May 2015).
[14] Mona Althonayan, Anastasia Papazafeiropoulou, "Evaluating the Performance on ERP Systems in King Saud University (KSU): A Stakeholders' Perspective", HICSS, 2013, 2014 47th Hawaii International Conference on System Sciences, 2014 47th Hawaii International Conference on System Sciences 2013, pp. 4074-4083, doi: 10.1109/HICSS.2013.210.

[15] Park, J.-H., Suh, H.-J., and Yang, H.-D. (2007) Perceived absorptive capacity of individual users in performance of Enterprise Resource Planning (ERP) usage: The case for Korean firms, Information \& Management, Vol. 44 No. 3, pp. 300-312.

[16] SAP news, (2015), available at: http://sapnews.tmcnet.com/news/2011/05/17/5514769.htm (accessed on May 2015).

[17] SAP news, (2015), available at: http://www.sap.com/mena/services/universityalliances/index.e px (accessed on May 2015).

[18] Saudi Arabian Higher Education Board (2015), available at: http://www.imamu.edu.sa/mangment_of_univirsity/University Council/Pages/the system of higher\% $\%$ 20 education.aspx (accessed on May 2015)

[19] Simon H, Alejandra R. (2014) Enterprise Resource Planning Systems and Users' Satisfaction. Umea School of Business and Economics. Umea University, Master thesis pp. 34-39.

[20] The collage of Davidson \& Davie counties, (2015), available at: https://www.davidsonccc.edu/catalog/academics (accessed on May 2015).

[21] University Avenue West Waterloo, (2015), available at: https://uwaterloo.ca/co-operative-education/studentperformance-evaluation (accessed on May 2015).

[22] University of South Carolina Upstate, (2015), available at: http://www.uscupstate.edu/offices/planning/assessment/Defaul t.aspx?id=10030 (accessed on May 2015). 